7. Reprod. Fert. (1967) 13, 31-40

\title{
ORIGIN OF THE ANTIGENS IN RABBIT SEMEN WHICH INDUCE ANTIFERTILITY ANTIBODIES*
}

\author{
A. G. MENGE and W. P. PROTZMAN \\ Department of Animal Sciences, New Fersey Agricultural Experimental Station, \\ Sussex, New Jersey, U.S.A.
}

(Received 18th December 1965, revised 12th April 1966)

Summary. Cattle and guinea-pig antisera against rabbit testis, epididymal spermatozoa and ejaculated semen had high titres of sperm agglutinins and prevented fertilization of ova in rabbits bred with semen treated with these sera. Although cattle antisera produced against seminal plasma from vasectomized rabbits, 9-day-old-rabbit conceptuses and rabbit brain and guinea-pig antiserum to seminal plasma containing epididymal secretions exhibited relatively high titres of sperm agglutinins, none of these sera prevented spermatozoa from fertilizing ova. The antifertility antibodies were removed or inactivated in antisera by absorptions with testis material, epididymal spermatozoa and semen supernatant but not by absorption with either type of seminal plasma.

Agar-gel diffusion and immuno-electrophoretic techniques revealed that ejaculated rabbit semen contained at least nine antigens. Seven were common to seminal plasma, two to blood serum and two appeared to be spermatozoa-specific originating in the testis. Antisera to the conceptus material reacted with four to six different antigens in semen of which at least one was not common to the antigens in blood serum.

\section{INTRODUCTION}

An antifertility effect has been reported in rabbits and cattle bred with semen that had been treated with antisera prepared against the homologous semen (Kiddy, Stone \& Casida, 1959; Menge, Stone, Tyler \& Casida, 1962b). Kiddy et al. (1959) observed that treating rabbit semen with low dilutions of antiserum prevented fertilization, whereas higher dilutions permitted fertilization but significantly increased embryo mortality. Embryo mortality was also induced in rabbits by injection of anti-semen serum into the uterine lumen between the embryonic sites on the 9th day of pregnancy (Menge, Kiddy, Stone \& Casida, 1962a). Lowered fertility has been reported in female guineapigs, rabbits and mice iso-immunized with testis or spermatozoa (Katsh, 1959; Isojima, Graham \& Graham, 1959; Behrman, Otani, Porter \& Nekayama, 1963; McLaren, 1964; Behrman \& Nakayama, 1965).

* Paper of the Journal Series, New Jersey Agricultural Experiment Station, Rutgers-The State University, New Brunswick. 
The origin of the antigens in semen has received considerable attention; however, the exact origin of the antigens that induce antibodies which cause infertility has not been reported. Weil (1960) observed that spermatozoa from the epididymis of rabbits lacked the antigens found on the ejaculated sperm cells. Later, Weil \& Rodenberg (1962) found that spermatozoa became coated with antigens from the seminal plasma. Hunter \& Hafs (1965) reported that rabbit semen contained nine antigens, seven common to seminal plasma and two specific for spermatozoa. These same authors (Hunter \& Hafs, 1964) found that bull spermatozoa possessed at least seven antigens of which five were shared with seminal plasma and one with blood serum.

The present study was undertaken to determine the origin of the antigens in rabbit semen that induce the antibodies which prevent spermatozoa from fertilizing ova in rabbits.

\section{MATERIALS AND METHODS}

Antigenic materials

Ejaculated semen was obtained weekly from six male rabbits by use of an artificial vagina. The semen was pooled and used immediately or stored at $20^{\circ} \mathrm{C}$ until used. Eight mature male rabbits were killed at various stages of the study to provide blood serum, brain tissue, testis material and epididymal spermatozoa. The brain and testis materials were homogenized in a Waring Blendor with equal volumes of physiological saline solution and then frozen. Epididymal spermatozoa were obtained by mincing the epididymides and grinding the tissue with saline solution in a glass tissue grinder. The spermatozoa concentration was adjusted to $1 \times 10^{8} \mathrm{cells} / \mathrm{ml}$ and used immediately or stored frozen. Several samples of epididymal spermatozoa were washed ten times with modified Krebs solution by centrifugation at $4200 \mathrm{~g}$ and resuspended to $1 \times 10^{8}$ cells $/ \mathrm{ml}$. Seminal plasma samples were of two types: one sample was obtained from two vasectomized rabbits and the other was from two rabbits with the caudal epididymides severed from the testes before puberty.

Conceptus material was obtained from female rabbits on the 9th day of gestation. This material was homogenized with a volume of saline solution equal to one-half the volume of the conceptus material in a glass tissue grinder and frozen until used.

\section{Immune sera}

Normal sera were obtained from all the animals before the first injection. All serum samples were heated at $56^{\circ} \mathrm{C}$ for $30 \mathrm{~min}$ before use. Antisera to rabbit semen, testis, epididymal spermatozoa, seminal plasma, conceptus material and brain tissue were produced in both cattle and adult guinea-pigs. In addition, antiserum to normal rabbit serum was produced in a heifer, and antiserum was produced in guinea-pigs to epididymal spermatozoa washed ten times. In cattle, the injection scheme was a series of three intradermal injections of $2 \mathrm{ml}$ of material consisting of equal parts of the antigenic material and Freund's complete adjuvant given at multiple sites. One or 2 weeks after the first injection the second injection was given. The third injection followed 
after an additional 3 or 4 weeks. Seven to 10 days after the last injection the animals were bled by venous puncture and the serum obtained. One animal furnished the antiserum to one antigenic material. In guinea-pigs 3-weekly injections, consisting of $0.5 \mathrm{ml}$ of antigenic material mixed with $0.5 \mathrm{ml}$ of Freund's complete adjuvant, were given subcutaneously and intramuscularly. One week after the third injection 8 to $10 \mathrm{ml}$ of blood was obtained by cardiac puncture. After an interval of 3 or 4 weeks the animals were reinjected and additional serum was procured. Antiserum to each antigenic material was obtained from two or three guinea-pigs.

Absorptions of antisera with testis material were performed by adding to a known volume of undiluted antiserum an equal volume of homogenized testis and incubating at $37^{\circ} \mathrm{C}$ for $30 \mathrm{~min}$. The mixture was then centrifuged at approximately $4200 \mathrm{~g}$ for $10 \mathrm{~min}$. The supernatant was removed and the absorption repeated a total of four times. Antiserum absorption with thricewashed epididymal spermatozoa was done by incubating $0.2 \mathrm{ml}$ of packed sperm cells with $1 \mathrm{ml}$ of $1: 2$ diluted antiserum for $30 \mathrm{~min}$ at $37^{\circ} \mathrm{C}$. The material was then centrifuged and the process repeated for a total of four absorptions. Absorption of antiserum to semen with semen supernatant and seminal plasma from vasectomized males was performed by diluting the serum 25 times with these fluids in five steps with intervening incubations at $37^{\circ} \mathrm{C}$ for $30 \mathrm{~min}$ and centrifugations at $4200 \mathrm{~g}$. Semen supernatant was obtained from whole semen by centrifuging twice at $4200 \mathrm{~g}$ for $10 \mathrm{~min}$ and then filtering through $1.20 \mu$ and $0.22 \mu$ microfilters (Millipore Filter Corporation).

\section{Semen treatment and insemination}

Rabbit semen was collected immediately before its use and kept at $37^{\circ} \mathrm{C}$ until diluted. Estimates of spermatozoa concentration were made with a haemocytometer chamber. The semen and serum samples were diluted to the desired concentrations with modified Krebs solution or saline solution, and after mixing, were incubated at $37^{\circ} \mathrm{C}$ for $15 \mathrm{~min}$ before insemination. The rabbits used were of mixed breeding and sexually mature. Females receptive to a male were inseminated with approximately 25 million spermatozoa in $0.5 \mathrm{ml}$ of the semen-serum mixture. Immediately before breeding the rabbits were injected intravenously with 100 i.u. of human chorionic gonadotrophin (HCG) to induce ovulation. The degree of spermatozoan motility and agglutination in the samples was estimated shortly after breeding.

Fertilization rates were determined by killing the rabbits 26 to $28 \mathrm{hr}$ after mating and recovering the ova by flushing the excised oviducts with saline solution. Ova were considered fertilized if they were cleaved and had apparently normal blastomeres.

\section{Immunological tests}

Sperm-agglutinin titres of the sera were determined by the gelatine agglutination method (Kibrick, Belding \& Merrill, 1952) as described in an earlier publication (Menge et al., 1962b). The spermatozoa used in the majority of the agglutination tests were from ejaculated semen samples; however, certain sera were tested using epididymal spermatozoa in the method. 
Double diffusion in agar gel $(1.0 \%$ solution of Noble agar in physiological saline solution) was performed according to the method described by Crowle (1961). The immuno-electrophoresis technique of Peetoom (1963) was also used to study the antigenic complexity of certain materials. This method utilized $1.0 \%$ Noble agar in Veronal buffer solution ( $\mathrm{pH} 8 \cdot 6$, ionic strength of 0.025 ). For use in the diffusion tests the samples of semen, epididymal spermatozoa, testis homogenate and conceptus homogenate were diluted with an equal volume of saline solution and stored overnight at $5^{\circ} \mathrm{C}$ or in the freezer before deposition in the wells. Supernatant samples of these materials were used in the immuno-electrophoretic studies.

TABLE 1

FERTILIZATION RATES IN RABBITS BRED WITH SEMEN TREATED WITH VARIOUS CATTLE SERA

\begin{tabular}{|c|c|c|c|c|}
\hline Serum & $\begin{array}{c}\text { Final } \\
\text { serum } \\
\text { dilution }\end{array}$ & $\begin{array}{l}\text { No. of } \\
\text { rabbits } \\
\text { bred }\end{array}$ & $\begin{array}{l}\text { No. of } \\
\text { ova } \\
\text { recovered }\end{array}$ & $\begin{array}{c}\text { Ova } \\
\text { fertilized } \\
(\%)\end{array}$ \\
\hline Normal serum & $1: 2$ & 8 & 71 & $94 \cdot 4$ \\
\hline $\begin{array}{l}\text { Antisera against: } \\
\text { Testis } \\
\text { Epididymal spermatozoa } \\
\text { Ejaculated semen } \\
\text { Seminal plasma } \\
\text { Conceptus } \\
\text { Brain } \\
\text { Serum }\end{array}$ & $\begin{array}{l}1: 5 \\
1: 5 \\
1: 5 \\
1: 2 \\
1: 2 \\
1: 2 \\
1: 2\end{array}$ & $\begin{array}{l}4 \\
4 \\
4 \\
2 \\
4 \\
2 \\
2\end{array}$ & $\begin{array}{l}41 \\
35 \\
34 \\
24 \\
46 \\
20 \\
13\end{array}$ & $\begin{array}{r}0 \cdot 0 \\
0 \cdot 0 \\
0 \cdot 0 \\
91 \cdot 7 \\
91 \cdot 4 \\
95 \cdot 0 \\
100 \cdot 0\end{array}$ \\
\hline $\begin{array}{l}\text { Testis-absorbed antisera } \\
\text { against: } \\
\text { Testis } \\
\text { Epididymal spermatozoa } \\
\text { Semen }\end{array}$ & $\begin{array}{l}1: 2 \\
1: 5 \\
1: 5\end{array}$ & $\begin{array}{l}2 \\
2 \\
2\end{array}$ & $\begin{array}{l}16 \\
17 \\
22\end{array}$ & $\begin{array}{l}93 \cdot 8 \\
94 \cdot 1 \\
81 \cdot 8\end{array}$ \\
\hline $\begin{array}{l}\text { Antisemen serum absorbed } \\
\text { with: } \\
\text { Epididymal spermatozoa } \\
\text { Seminal plasma } \\
\text { Semen supernatant } \\
\text { Saline solution }\end{array}$ & $\begin{array}{l}1: 5 \\
1: 30 \\
1: 30 \\
1: 30\end{array}$ & $\begin{array}{l}2 \\
2 \\
2 \\
2\end{array}$ & $\begin{array}{l}18 \\
19 \\
20 \\
17\end{array}$ & $\begin{array}{r}94.4 \\
0.0 \\
95 \cdot 0 \\
0.0\end{array}$ \\
\hline $\begin{array}{l}\text { Normal serum* } \\
\text { Antisemen serum* }\end{array}$ & \} $1: 4$ & 2\{ & $\begin{array}{r}9 \\
12\end{array}$ & $\begin{array}{r}88.9 \\
0.0\end{array}$ \\
\hline
\end{tabular}

* The treated spermatozoa were injected into the oviducts of the two rabbits (see text).

\section{RESULTS}

Antifertility effects of antisera

Bovine antisera produced against testis, epididymal spermatozoa and ejaculated semen completely inhibited fertilization of ova when used to treat semen before insemination of twelve rabbits (Table 1). However, treatment of semen with bovine normal serum and antisera to rabbit serum, brain, seminal plasma and 9-day-old conceptuses permitted fertilization rates ranging from 91 to $100 \%$.

To determine if the antigens that induced the antifertility effect of the 
antisera to testis, epididymal spermatozoa and ejaculated semen originated within the testis, these antisera were absorbed with homogenized testis material and then used to treat semen. This procedure removed the antifertility effect as normal fertilization rates were obtained in two rabbits for each serum sample. Similarly, the absorption of antiserum to semen with epididymal sperm cells resulted in removal of the antibodies causing fertilization failure. Diluting the antisemen serum with saline solution, seminal plasma and supernatant from ejaculated semen resulted in only the latter dilution inhibiting the antifertility effect of the serum as determined by fertilization rates.

Washing and thoroughly mixing spermatozoa three times with modified Krebs solution after the cells had been incubated with antisemen serum for 15 $\min$ at $37^{\circ} \mathrm{C}$ did not remove the inhibition to fertilization in two rabbits bred with these spermatozoa. The does had been laparotomized $8 \mathrm{hr}$ after HCG injection and 2 to 3 million of the treated spermatozoa were injected into the right oviduct and in the left oviduct a similar number of spermatozoa were

TABLE 2

FERTILIZATION RATES IN RABBITS BRED WITH SEMEN TREATED WITH VARIOUS GUINEA-PIG SERA

\begin{tabular}{l|c|c|c|c}
\hline \multicolumn{1}{c|}{ Serum } & $\begin{array}{c}\text { Final } \\
\text { serum } \\
\text { dilution }\end{array}$ & $\begin{array}{c}\text { No. of } \\
\text { rabbits } \\
\text { bred }\end{array}$ & $\begin{array}{c}\text { No. of } \\
\text { ova } \\
\text { recovered }\end{array}$ & $\begin{array}{c}\text { Ova } \\
\text { fertilized } \\
(\%)\end{array}$ \\
\hline Normal serum & $1: 2$ & 4 & 41 & $97 \cdot 6$ \\
Antisera against: & $1: 5$ & 2 & 19 & $0 \cdot 0$ \\
$\quad$ Testis & $1: 20$ & 2 & 20 & $0 \cdot 0$ \\
Semen & $1: 100$ & 1 & 13 & $0 \cdot 0$ \\
Semen & $1: 5$ & 2 & 21 & $0 \cdot 0$ \\
Epididymal spermatozoa & $1: 2$ & 2 & 21 & $100 \cdot 0$ \\
Seminal plasma & $1: 2$ & 2 & 23 & $95 \cdot 6$ \\
\hline
\end{tabular}

placed that had been washed after incubation in normal serum. Whereas sperm treatment with normal serum permitted fertilization, the antifertility effect of the antiserum treatment still persisted.

The results with guinea-pig antisera were similar to those obtained with the cattle sera (Table 2). Again normal serum permitted a high fertilization rate in rabbits, whereas fertilization was inhibited in does bred to semen treated with antisera to semen and testis. Epididymal spermatozoa that had been washed ten times still possessed antigens capable of inducing the antifertility antibodies in guinea-pigs. Treatment of rabbit semen with these antibodies completely blocked fertilization. Guinea-pig antiserum to seminal plasma from the males with the caudal epididymides severed from the testes and antiserum to conceptus material, as had the cattle antisera, permitted normal fertilization rates after semen treatment.

The motility of spermatozoa in the various serum-semen samples ranged from 50 to $70 \%$ with no apparent relationship to the fertilizing ability of the individual samples. 
Immunological tests

The results of the spermatozoa agglutination tests revealed that cattle normal serum and antiserum to rabbit serum exhibited weak titres which were presumably due to naturally occurring antibodies cross-reactive with rabbit spermatozoa (Table 3). Conversely, antisera to testis, epididymal spermatozoa, semen, seminal plasma and conceptus possessed relatively high titres of sperm agglutinins and the antiserum to brain tissue a slightly lower titre. The agglutinins were largely removed from the antisera against the germinal tissues by absorption with testis material or epididymal spermatozoa. The dilution of antiserum to semen with seminal plasma from vasectomized rabbits moderately reduced the agglutination titre compared with the supernatant of ejaculated semen which greatly decreased the titre. However, both of these materials removed the agglutinins from antisera to seminal plasma.

TABLE 3

TITRES OF SPERM AGGLUTININS IN VARIOUS CATTLE AND GUINEA-PIG SERA*

\begin{tabular}{|c|c|c|c|c|c|c|c|c|}
\hline \multirow{2}{*}{ Type } & \multirow{2}{*}{$\begin{array}{c}\text { Normal } \\
\text { sera }\end{array}$} & \multicolumn{7}{|c|}{ Antisera against } \\
\hline & & Testis & $\begin{array}{c}\text { Epididy- } \\
\text { mal sperm }\end{array}$ & $\begin{array}{c}\text { Ejaculated } \\
\text { semen }\end{array}$ & $\begin{array}{l}\text { Seminal } \\
\text { plasma }\end{array}$ & Conceptus & Brain & Serum \\
\hline Cattle & 16 & 512 & 1024 & 2048 & 4096 & 2048 & 256 & 32 \\
\hline $\begin{array}{l}\text { Cattle absorbed with: } \\
\text { Testis } \\
\text { Epididymal sperm } \\
\text { Seminal plasma } \\
\text { Semen supernatant }\end{array}$ & $\begin{array}{l}\text { NT } \dagger \\
\text { NT } \\
\text { NT } \\
\text { NT }\end{array}$ & $\begin{array}{l}8 \\
<10 \\
\text { NT } \\
\text { NT }\end{array}$ & $\begin{array}{r}32 \\
10 \\
\text { NT } \\
\text { NT }\end{array}$ & $\begin{array}{r}128 \\
10 \\
200 \\
<25\end{array}$ & $\begin{array}{l}\text { NT } \\
\text { NT } \\
<25 \\
<25\end{array}$ & $\begin{array}{l}\text { NT } \\
\text { NT } \\
\text { NT }\end{array}$ & $\begin{array}{l}\text { NT } \\
\text { NT } \\
\text { NT } \\
\text { NT }\end{array}$ & $\begin{array}{l}\text { NT } \\
\text { NT } \\
\text { NT } \\
\text { NT }\end{array}$ \\
\hline Guinea-pig & $<4$ & 512 & 1024 & 4096 & 1024 & $<4$ & $<4$ & NT \\
\hline $\begin{array}{l}\text { Tested with epididymal } \\
\text { spermatozoa } \\
\text { Cattle } \\
\text { Guinea-pig }\end{array}$ & $\begin{array}{r}8 \\
<4\end{array}$ & $\begin{array}{l}256 \\
512\end{array}$ & $\begin{array}{l}1024 \\
1024\end{array}$ & $\begin{array}{l}1024 \\
2048\end{array}$ & $\begin{array}{l}1024 \\
1024\end{array}$ & $\begin{array}{c}1024 \\
\text { NT }\end{array}$ & $\begin{array}{l}\text { NT } \\
\text { NT }\end{array}$ & $\begin{array}{l}\text { NT } \\
\text { NT }\end{array}$ \\
\hline
\end{tabular}

* Titre recorded as reciprocal of the highest dilution of the serum giving a positive reaction. $\dagger \mathrm{NT}=$ not tested.

The agglutination titres of the guinea-pig antisera were generally comparable to those of the cattle sera with two exceptions: guinea-pig antisera to conceptus material and brain tissue gave the same non-specific reactions as guinea-pig normal serum which is in contrast to the titres exhibited by the cattle antisera to those materials. The relatively high titre of agglutinins produced in guineapigs against the epididymal spermatozoa that had been washed ten times indicates the relative degree of antigenicity of these cells from the epididymis.

Substituting spermatozoa from the epididymis for the ejaculated sperm cells in the agglutination tests resulted in only slight changes in the titre levels for the cattle and guinea-pig antisera to testis, epididymal spermatozoa, semen and, surprisingly, also the seminal plasmas.

The antigenic systems and tissue cross-reactions were evaluated by immunoelectrophoresis and agar-gel double diffusion. Immuno-electrophoresis of seminal materials and the reaction with bovine antiserum to semen revealed 

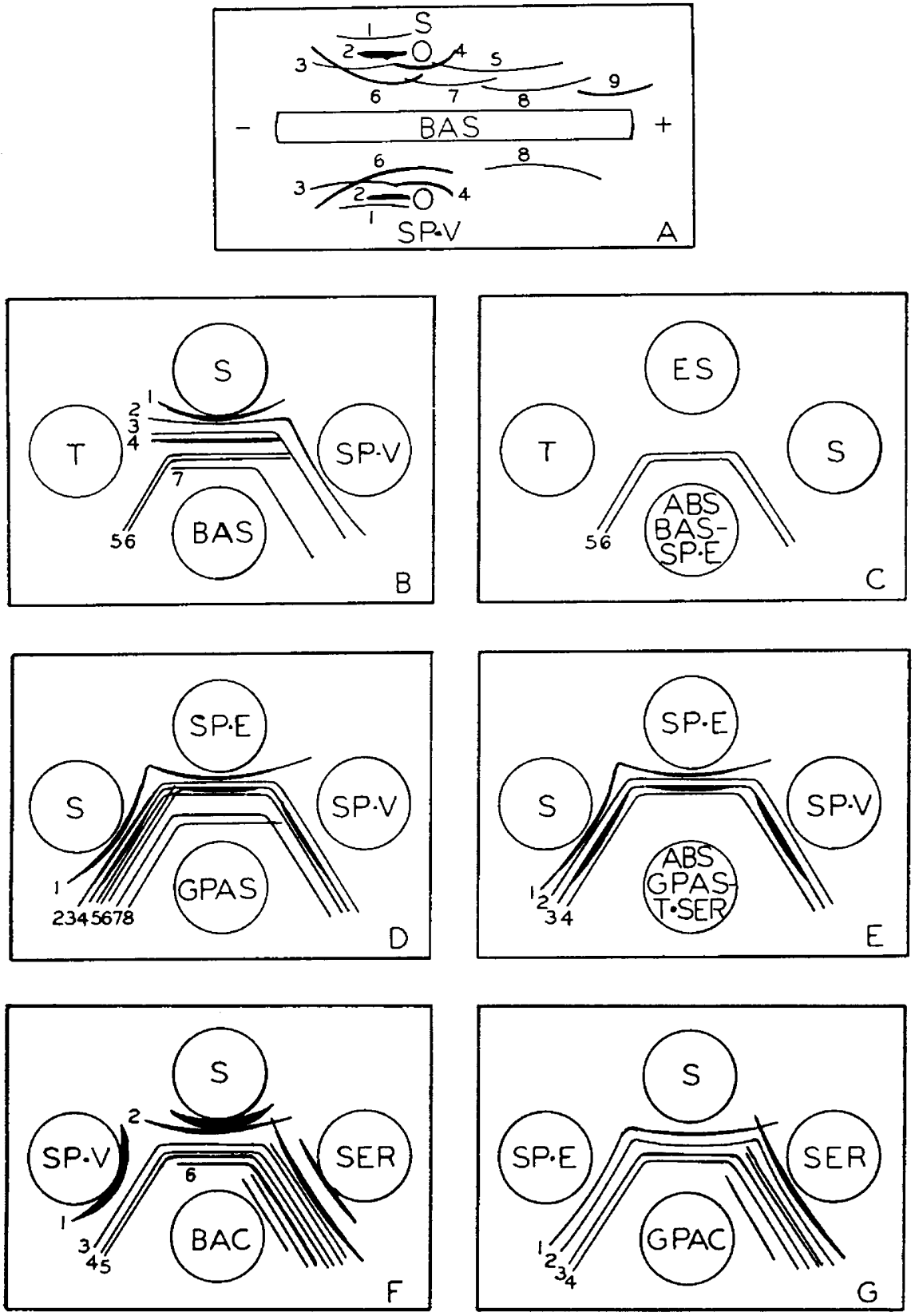

TEXT-FIG. 1. Precipitin reactions of bovine and guinea-pig antisera with rabbit testicular, seminal and serum materials. (A) is a diagram of an immuno-electrophoresis plate and (B) to (G) are diagrams of agar-gel diffusion plates. Abbreviations: $\mathbf{s}=\mathbf{s e m e n \text { ; }}$ SP.V = seminal plasma from vasectomized males; SP.E = seminal plasma from males with epididymides severed from testes; $E S=$ epididymal spermatozoa; $T=$ testis material; SER = blood serum; BAS = bovine antisemen serum; ABS BAS-SP.E $=$ BAS absorbed with SP.E; GPAS = guinea-pig antisemen serum; ABS GPAS-T.SER = GPAS absorbed with testis and serum; BAC = bovine anti-rabbit conceptus; GPAC = guinea-pig anti-rabbit conceptus. 
nine antigens in rabbit semen of which six were found in seminal plasma from vasectomized male rabbits (Text-fig. 1A). Three arcs (5, 7 and 9) remained after the antiserum was absorbed with the seminal plasma. The double diffusion technique using the bovine antiserum indicated that the testis contributed two antigens to semen which appeared to be sperm specific as they were present in washed epididymal spermatozoa but not in seminal plasma (Text-fig. $1 \mathrm{~B}$ and $\mathrm{C}$ ). Absorption of the antiserum with seminal plasma containing epididymal secretions did not remove the precipitins for these two antigens; however, they were removed by absorption with washed epididymal spermatozoa and testis material. Reactions with guinea-pig antiserum to rabbit semen showed the presence of eight antigens in semen of which two originated in the testis, two in the epididymis and four in the fluids from the accessory glands and seminal tract (Text-fig. 1D). Absorption of the antiserum with serum and testis material revealed that two of the antigens forming precipitin lines ( 7 and 8) were common with serum antigens and two other antigens represented in bands 5 and 6 were of testicular origin (Text-fig. 1E). These results indicate that of the nine detectable antigens in rabbit semen two are sperm specific originating in the testes and seven are from secretions of the epididymides, accessory glands and seminal tract of which two are common to serum antigens.

Both bovine and guinea-pig antisera to rabbit conceptus material formed precipitin bands with rabbit semen which indicated at least six and four common antigens, respectively, between semen and conceptus material (Textfig. $\mathrm{IF}$ and $\mathrm{G}$ ). One of these antigens which originated in the epididymis was observed to be semen specific as it was not similar to the serum antigens. This specific antigen-antibody precipitin line was not present in reactions involving antisera that had been absorbed with seminal plasma containing epididymal secretions.

\section{DISCUSSION}

The results indicate quite clearly that in the rabbit the source of the semen antigens that induce antibodies capable of preventing spermatozoa from fertilizing ova is in the testis. This is indicated by the removal or inactivation of the antifertility antibodies in antiserum to semen by absorptions with testis tissue, washed epididymal spermatozoa and semen supernatant but not by seminal plasma from the operated males. Additional evidence is the lack of the antifertility effect of antisera produced against serum, seminal plasma with and without epididymal secretions, whole brain, and 9-day-old conceptus material. The cattle antisera to these materials, with the exception of serum, and the guinea-pig antiserum to seminal plasma possessed relatively high levels of sperm agglutinins and caused heavy flocculation of spermatozoa. This would indicate that the inhibition of fertilization by antibodies is due to other factors than merely the agglutination of the sperm cells. Spermatozoa once exposed to the antifertility antibodies did not regain their fertilizing capacity after three washings and dispersing of the clumps, suggesting that a relatively irreversible effect had occurred on or in the cells which prevented them from fertilizing ova.

Hunter \& Hafs (1965) reported that rabbit semen possessed at least nine antigens of which two were specific to spermatozoa. Our results agree with their 
findings and the evidence suggests that one or both of the sperm-specific antigens are involved in the antifertility reactions. The possibility still exists, however, that cell-fixed antigens, which are difficult to detect, could be involved. The removal of the antifertility effect of antisemen sera by absorption with semen supernatant argues against this. As has been reported by other workers (Weil, 1960; Weil \& Rodenburg, 1962; Hunter \& Hafs, 1965) and is evident in this study, the majority of the antigenic components of semen originate from the accessory glands and seminal tract.

Kiddy et al. (1959) were not only able to prevent fertilization in rabbits by the treatment of semen with antisemen serum but also increased the incidence of embryo mortality. The direct treatment of 9-day-old embryos by intrauterine injection of antisemen serum was shown by Menge et al. (1962a) also to increase the mortality rate. It appears that, in female animals immunized with homologous testis or spermatozoa, an induced infertility occurs (Katsh, 1959; Isojima et al., 1959; Behrman et al., 1963; Edwards, 1964; McLaren, 1964; Behrman \& Nakayama, 1965). Weil \& Roberts (1965) failed to induce infertility in female rabbits by iso-immunization with semen supernatant. However, the quantity of supernatant used was quite small and in view of our absorption results with semen supernatant it appears that the proper antigens were too limited to induce a sufficient titre of antifertility antibodies. Whether the infertility resulting from iso-immunization with semen and testis is due to fertilization failure, embryo death or a combination of these two factors is not fully known, though McLaren indicated fertilization failure was the main cause of infertility in mice iso-immunized with spermatozoa. It is likely that in both the heterologous and homologous systems the seminal antigens which induce the antifertility antibodies are identical and are sperm specific. Iso-antisera from rabbits injected with semen, testis and washed epididymal spermatozoa were capable of preventing spermatozoa from fertilizing ova in other female rabbits (unpublished results). The present results and those of Kiddy et al. 1959 and Menge et al. (1962a, 1962b) suggests that infertility could result from a combination of the two factors with the responsible antibodies being active at the time of fertilization and possibly later after the embryo loses the zona pellucida. The presence of at least one common antigen in semen and conceptus material which is not found in blood serum supports the latter report (Menge et al., 1962a) indicating that antibodies against semen could directly affect the conceptus.

\section{ACKNOWLEDGMENTS}

This investigation was supported by a PHS Research Grant, GM-11130, from the Division of General Medical Sciences, Public Health Service. We are grateful to Dr R. J. DeFalco for valuable advice and the use of certain equipment and to Mr D. Kramer for technical assistance.

\section{REFERENGES}

Behrman, S. J. \& Nakayama, M. (1965) Antitestis antibody: Its inhibition of pregnancy. Fert. Steril. 16,37 .

Behrman, S. J., Otani, Y., Porter, C. W. \& Nakayama, M. (1963) Reduction of fertility in immunized guinea pigs. Int. F. Fert. 8, 835. 
Crowle, A. J. (1961) Immunodiffusion. Academic Press, New York.

Edwards, R. G. (1964) Immunological control of fertility in female mice. Nature, Lond. 203, 50.

Hunter, A. G. \& Hafs, H. D. (1964) Antigenicity and cross-reactions of bovine spermatozoa. $\mathcal{J}$. Reprod. Fert. 7, 357.

Hunter, A. G. \& Hafs, H. D. (1965) Differentiation of sperm protein from that of seminal plasma in rabbits. Fedn Proc. Fedn Am. Socs exp. Biol. 24, 700.

Isojima, G., Graham, R. M. \& Graham, J. B. (1959) Sterility in female guinea pigs induced by injection with testis. Science, N.Y. 129, 44.

Katsh, S. (1959) Infertility in female guinea pigs induced by injection of homologous sperm. Am. $\mathcal{F}$. Obstet. Gynec. 78, 276.

Kibrick, S., Belding, D. L. \& Merrill, B. (1952) Methods for the detection of antibodies against mammalian spermatozoa. Fert. Steril. 3, 419.

Kiddy, C. A., Stone, W. H. \& Casida, L. E. (1959) Immunological studies on fertility and sterility. II. Effects of treatment of semen with antibodies on fertility in rabbits. 7. Immunol. 82, 125.

McLaren, A. (1964) Immunological control of fertility in female mice. Nature, Lond. 201, 582.

Menge, A. C., Kiddy, C. A., Stone, W. H. \& Casida, L. E. (1962a) Immunological studies on fertility and sterility. V. Effect of antibodies against semen and erythrocytes on rabbit embryos. $\mathcal{F}$. Reprod. Fert. 4, 87.

Menge, A. C., Stone, W. H., Tyler, W. J. \& Casida, L. E. (1962b) Immunological studies on fertility and sterility. IV. Fertility of cattle and rabbits inseminated with semen treated with antibodies produced against semen, spermatozoa and erythrocytes. F. Reprod. Fert. 3, 331 .

Ревтоом, F. (1963) The agar precipitation technique and its application as a diagnostic and analytical method. Charles C. Thomas, Springfield, Illinois.

WEIL, A. J. (1960) Immunological differentiation of epididymal and seminal spermatozoa of the rabbit. Science, N.r. 131, 1040.

WeIL, A. J. \& RoBerts, C. O. (1965) Fertility of female rabbits after isoimmunization with seminal plasma. Fert. Steril. 16, 356.

Weil, A. J. \& Rodenburg, J. M. (1962) The seminal vesicle as the source of the spermatozoa-coating antigen of seminal plasma. Proc. Soc. exp. Biol. Med. 109, 567. 